\title{
Food security and sustainability: exploring Japanese youth participation in agriculture
}

\author{
${ }^{1,{ }^{*}}$ Saili, A.R., ${ }^{2}$ Saili, J., ${ }^{1}$ Aziz, A.S.A., ${ }^{1}$ Kamil, M.Z. and ${ }^{3}$ Aziz, N.N.H. \\ ${ }^{1}$ Faculty of Plantation and Agrotechnology, Universiti Teknologi MARA, Jalan Meranek, 94300, Kota \\ Samarahan, Sarawak, Malaysia \\ ${ }^{2}$ Faculty of Cognitive Sciences and Human Development, Universiti Malaysia Sarawak, Jalan Datuk \\ Mohammad Musa, Kota Samarahan, 93400 Malaysia \\ ${ }^{3}$ Faculty of Plantation and Agrotechnology, Universiti Teknologi Mara (UiTM), Cawangan Melaka, \\ Kampus Jasin, 77300 Merlimau, Melaka, Malaysia
}

Article history:

Received: 23 July 2020

Received in revised form: 1

December 2020

Accepted: 11 December 2020

Available Online: 20

December 2020

Keywords:

Japan agriculture,

Ageing farmers,

Sustainable agriculture,

Food security,

Youth

DOI:

https://doi.org/10.26656/fr.2017.4(S5).021

\begin{abstract}
There are many challenges in assuring the sustainability of food supply in the context of expanding Japanese population. Insufficient participation of Japanese youth in the agricultural industry is among the issues in food sustainability which has prompted the Japanese government to ensure more youth engagement in the sector for its continuity. The youth are considered as vanguards who would bring changes in the Japanese agriculture industry as the number of ageing farmers in the country is increasing. In Japan, agriculture is one of the most important industries as it contributes about $1.1 \%$ to overall national GDP. Thus, a qualitative study with a phenomenological approach was conducted with 7 Japanese youth who are involved in the agriculture industry in the country to identify their socio-economic characteristics, to determine the factors influencing their participation and the constraints, and to assess the perceptions, perspectives, and understandings of youth towards food security, safety and sustainability in agriculture development. The in-depth face-to-face interviews were used to collect data from 7 young Japanese farmers using both purposive and snowball sampling based on the availability of youth farmers in Japan. The data were analysed and categorized into 5 broad themes. The analysis revealed that family support, tradition, passion, economic factor, and working environment are the factors that influence their participation in the industry. It can be suggested that participation of youth in Japan agriculture industry can be nurtured and sustained with several promotional approaches to youth on what the industry can offer them and their country in the future. Moreover, the motivational drive from their families would undoubtedly encourage them to join the industry. These findings are expected to have significant information and knowledge to extend the literature on Japanese youth participation in agriculture and help formulate the action plan needed for the youth development strategies for Japan agriculture in the future.
\end{abstract}

\section{Introduction}

The agriculture sector is one of the main sectors that contributes to the economic growth of many countries in the world such as Japan. Due to its unlimited demand for agricultural products, individuals who participate in the industry are faced with many opportunities and challenges. On top of that, agricultural sector encompasses a various group of industries around the globe that includes farming, stock farm, fisheries, food processing, non-food processing, plantation, and others (Silva et al., 2010).
Japan is an island nation situated off the eastern seaboard of the Eurasian continent in the northern hemisphere. Agriculture is considered one of the most important industries in Japan after industrial and services industry. Japan's agricultural economy is highly supported and protected by the Japan government. However, according to Hays (2009), Japan has a severe lack of agricultural land. Although $15 \%$ of Japanese land are suitable for agriculture, this available land is fully utilized with the cultivation and production of agricultural produce. As such, Japan has one of the 
highest per hectare crops yields in the world (EconomyWatch, 2013).

In light of the importance of agriculture industry in the country, the participation of young generation has become more significant due to the current trends of participation of two distinct generations - the younger generation of farmers and the older generation of farmers. However, ageing farmers, who constitute the major farming population are seen as the main group of farmers who manage and operate the agricultural land with few younger farmers involved. According to Abdullah and Sulaiman (2013), younger generations are inclined to find jobs in factories and commercial sectors as opposed to the farming industry. Another setback faced by the Japanese government was an ageing population and low birth rate which have been affecting several industries including agriculture. According to Hays (2012), the farmers were getting older and only a few youths who stepped forward to take their place which has contributed to the declining number of farmers. It is also supported by Feldhof (2014) who found that Japan's farming population were already dominated by the elderly in their 65 years of age and over. This condition presents a threat to the future of food security and sustainability in Japan. Besides, the lack of youth involvement in the agriculture industry can be associated with the negative perceptions towards agriculture sector itself as many of them view this sector as the industry that allows for a hard, heavy, and dirty job but not in other industries. This is in line with the finding by Leavy and Hossain (2014), who argued that youth, who represent a significant resource in agriculture and the rural economy has developed such perceptions towards agriculture.

The next issue is related to Japan's self-sufficiency level. It can be said that Japan has a low self-sufficiency level as the country is still relying on most of its imported products from other countries. According to Yamashita (2019), the food sufficiency of Japan's calorie -based rate in fiscal 2018 has fallen to $37 \%$ which is considered as low, based on the statement by The Agriculture Ministry of Japan. If the trend continues, Japan will have an issue related to the food sufficiency level and security in the future.

The unlimited prospect and opportunities this industry has to offer should able to help and encourage younger generations who are motivated to be in the industry. According to Filmer and Fox (2014), agriculture industry provides voluminous employment opportunity for the younger generation as non-farm sectors will be flocked with their counterparts in the future. The sustainability and stability of income that the industry can offer will also attract more youth to be involved in the industry. This has highlighted the prospect and opportunities for their future through agriculture.

One of the solutions to address the issues in agriculture is through the constant increase of youth involvement in the industry. Therefore, several initiatives and efforts can be done to encourage the participation of youth in agriculture. According to Mangal (2009), agriculture is associated with slow and outdated technology with less utilization of gadgets and the latest technology. Therefore, this perception has caused youth to steer away from the agricultural industry itself. However, with the implementation of modern technology in farming and other agricultural areas, it will attract youth to participate in the industry (Phyo, 2018) as the use of modern technology in farming can attract youth due to their preferences towards innovation and invention. This is supported by Brooks et al. (2013), who stated that agriculture will need to be as attractive as possible, and agriculture is more suitable for the youth as they possess features that are significant to be in the agriculture industry such as health and physical strength.

Therefore, this research was framed with the rationale and intention to identify the socio-economic characteristics of young Japanese farmers, understand the factors that contribute towards their participation in agriculture, and assess the perceptions, perspectives, and understandings of youth towards food security, safety, and sustainability in Japanese agriculture development.

\section{Methodology}

Japan was identified as the sampling frame of the study because it is one of the leading agriculture countries in the world. The participants were 7 young farmers from the areas of Nagoya, Aichi, Aizu, Nishiaizu dan Nagano. The areas were chosen due to the demographic description that matches the research criteria and availability of participants for the interview session. All participants are self-employed farmers who are involved in any of the major, secondary, and shorttermed crops plantations in Japan, aged between 18 and 40 years. A qualitative method with a phenomenology approach was chosen as the research method for this study because it allowed for comprehensive insights into the lived experience from the perspective of the young farmers. Sampling was made using both purposive and snowball sampling. The participants' accounts of their participation in agriculture along with their beliefs and feelings were tape-recorded in semi-structured interviews, transcribed, and subjected to Interpretative Phenomenological Analysis (Smith and Osborn, 2003). 
The interviews were conducted with the help of a local translator from Japanese to English. The participants were initially asked about their willingness to contribute to the study. According to Kumar (2011), it is unethical in research conduct to obtain data without the participants' knowledge and willingness. Therefore, the researcher made it clear to all participants that their involvement was from their intention to voluntarily participate in the study and they are without any obligation to withdraw at any time. Each interview was qualitatively and manually analyzed by searching for recurring themes across a data set. For this study, the thematic analysis was driven by a few particular analytic questions. In this case, the identified themes and codes in the analysis reflected an accurate content of the entire set in the interviews. The data were then categorized to respective broad themes which highlighted the factor affecting their participation in agriculture.

\section{Results}

\subsection{Theme 1: family support}

There are a lot of challenges and barriers to farming. However, some of the challenges in terms of managing the farm can be addressed through family support. Most youths in Japan are involved in agriculture through their family farming because it has become a tradition for the new generation to continue farming. Masahiro for example, had been farming for 15 years on his father's land:

I've been working my fathers' land and as a farmer for almost 15 years. Also, I don't hire any permanent workers because I have my parents, wife, siblings and part-time workers to operate on my farm. (Masahiro)

Farming can be laborious that requires a great deal of effort, especially in the harvesting period. Therefore, Japanese farmers tend to ask help from their family members and work with their family members only, rather than hiring others outside their family circle. Three participants mentioned that they usually ask for help from their family members to run farm activities:

Usually, my mother and I work together on the farm. During the peak of farming period such as harvesting season, I normally receive help from my mother and brother. (Sakae)

When my mother or my wife fall sick, my brother and sister will help me. They usually help me during tough times such as the harvesting period. (Hiroya)

I don't receive any assistance from the government. However, the customers are still buying from us because of their loyalty towards my grandmother who owns the farm. (Toyo)

Most of the participants agreed that they have been exposed to farming from their family members such as parents and grandparents since they were young:

I started farming since I was 23 years old and have not attended any training or course related to farming. I learned it from my family. (Sakae)

After graduating from university, I started farming straight away with my grandfather and mother. This has become my full-time job. (Hiroya)

My parents are farmers and I learnt farming from them. So, I don't have any formal training. (Tasaki-san)

Before I began my career in farming, I did not attend any farming course or training because I learnt it from my family along the way" (Itto-san)

\subsection{Theme 2: family tradition}

It is a tradition in Japan that the successor of a family farm is among the family members themselves. Most of the participants acknowledged that their engagement into farming is due to this tradition and their sense of responsibility to take over the farm:

My father motivates me to become a farmer. I am the only son in the family, and I have three elder sisters. I am also the youngest sibling. When I went to Tokyo for work, I already knew and felt that I would come back to my hometown to work on the farm because my ancestors and parents are farmers for generations. (Tasaki)

I do not want to take over my parents' farming job but it is because of responsibility. I have been pressured by my father to work on the farm. (Sakae)

My father does not want me to become a farmer. He died last year. But it is my responsibility to continue his work for my mother and my wife. (Masahiro)

The other two participants were not reluctant to change or quit their jobs just to continue their family farming:

It was not difficult to decide on quitting from the Motorola company. I was determined to do so because of my father. When I was 29 years old, I knew my father had cancer. So, I worked for the company for a while and resigned to help my father with the farming. Later when I was 30, my father died. (Itto)

I intended to change my job while I was working in a company because my father is a farmer. We have been planting all the fruits and rice for our family for generations. (Tsukada) 
The participants agree that farming is considered a tradition and a bond that has kept businesses in the family for generations. Moreover, they also considered farming as a proud family tradition that has been in the family's heritage.

My grandmother is a farmer. I am the 5 th generation in this family farm. Long ago when my grandmother was still in the farm, I used to do farming work and helped her. I am interested in farming because of my grandmother. (Toyo)

Farming is a family tradition. Even though some people might think that there is nothing special with farming, I am proud to continue my family's legacy. (Tsukada Shiro)

\subsection{Theme 3: passion}

Majority of the participants associated passion and motivation as the driving force that maintains their enthusiasm in farming. Most of the participants indicated that they are passionate in what are they doing:

When I work for Motorola, my salary was stable but not so good. However, there was not so much pressure, because I came to work and went home at a regular time. I think farming is a very tough job, but if I work hard, I will get what I deserve. That has been the key that keeps me moving. Hence if there is an opportunity or lucrative job offers in the city, I will not go for it. I want to become a farmer forever. (Itto)

Even if I was given an opportunity to work in an office, I will not go for it. I still want to continue farming. (Hiroya)

My heart told me to keep farming forever and I don't think of changing this job. (Masahiro)

I am not being pressured to become a farmer. It was my own decision and also, of course, the support from my family. (Tasaki)

One participant goes to the extent of confessing that he enjoys farming as he can see his plant grow day by day:

I think I can become a successful farmer because I enjoy farming. I am very happy to see the paddy grows in the rice field. I cannot wait to receive a lucrative profit from my farm. For your information, I received an award last year for producing good quality rice. (Sakae)

On the other hand, another participant admitted that there is hardship in farming especially during the peak of the farming season. Tsukada mentioned that he had to work the whole day since early in the morning to cope with various farming works. He added further that his income from farming activities is not consistent but there are always other ways to supplement what he earns, especially during winter. However, he continues farming due to his passion in it:

On the busiest season, I have to work in the early morning until late. No holiday including weekend. It is tough but I enjoy my life. I want to keep on farming. Even though the income is inconsistent, there will always some other work to do. In winter, there would be no farming but still can-do other part-time work. (Tsukada)

One of the participants did not leave the family farm although he is working in a company as he decided to keep the farm:

After graduation, I started working with Japanese Agriculture (JA) and as a part-time farmer as well. Then, I stopped working with JA and joined a management company. But I still take care of my own farm. (Toyo)

\subsection{Theme 4: economic factor}

Profit from farming activities has undoubtedly become a major concern to the farmers. Most of the youths agreed that successful agribusiness always offer a good profit return:

My income is around 10 million Yen per year and the profit is about $45 \%$ from it. (Hiroya)

For my company, the income is around 11 million Yen per year. (Tasaki)

The income for one year depends on the particular year and the market price. It's usually about millions of yens. After considering other costs such as a farming machine, I earn about 7 million Yen per year. (Itto)

My income for one year is less than 10 million Yen. I usually begin harvesting from end of October to November with 7 different kinds of apples. (Tsukada)

This was supported by Mr Toyo when he stated that he can become his own boss and earned lucrative income from farming:

When farming, I become the boss. I can earn a profit around 2 million per year. But in Japan, average farmer income is 3 million per year. (Toyo)

Most of the respondents claimed that due to profitable return, they have expanded their farm by renting more land to increase their farms' production.

I operate 13 hectares of land currently. 8 hectares of the land belong to my father and the other 5 hectares are being rented from someone else. I utilize all the land for 
cucumber and paddy plantation. (Itto-san)

Mainly, I farm rice and vegetables and I have 16 hectares of land for farming now. About $80 \%$ of the land is not owned by me because I am renting it. (Tasaki-san)

$20 \%$ of this land is not mine. It belongs to my neighbours. I am only paying rent. (Hiroya Tajima)

I have 1.4 hectares of land. 1 hectare is owned by my family while the rest is being rented from others. (Tsukada Shiro)

\subsection{Theme 5: working environment}

The working condition in a farm is very distinct from other job sectors such as factory or office environment in which the farm offers a stress-free work environment surrounded by nature. Besides that, farming offers a flexible working schedule because the farmer works on his own pace and time. The qualitative data revealed that most participants agreed that they like to reconnect with nature and live a stress-free life:

I live in a very small area in the mountain which is far away from a busy life. (Sakae)

It is my father's idea for me to get involved in farming. Until at one point, I'm in love with nature. Besides that, I enjoy managing my own business. I do not want to work in a company. I want to be my own boss. (Masahiro)

I will not quit from agriculture because I love such a quiet place like here. Even though working in Tokyo is good, but I feel so stress with my life over there. (Tasaki)

In light of the farming working environment, Toyo preferred the flexible work schedule:

I can do farming at my own time. And I can choose when I want to start working. (Toyo)

Furthermore, Mr Hiroya mentioned that he had to look for jobs in other sectors but could not find any that suited his desires. Instead, he returned to his farm and began farming because he was a person that dislike working in an office setting:

I did look for jobs in industrial places, but I cannot find a suitable job in any company. I prefer to work on my own as a farmer and I don't want to work in an office with other people. (Hiroya)

\section{Discussion}

It is one of many traits in Japanese culture that family support and family tradition play a significant role in supporting the children especially the sons to continue working on their family farm. The finding of this current study is consistent with Otomo and Oedl-Wieser (2009) who stated that Japanese traditional family institution, the "Ie", maintains and passes on material and spiritual family properties such as land and equipment. The "Ie" ideology, with its stem-family household structure, designated the eldest son as heir, expecting his family to live together with his parents. Peoples and Bailey (2015) mentioned that Japan's industrial production grew rapidly in the 1960s and rural-to-urban migration picked up as younger sons left for the cities despite their parents still expected their eldest sons to remain working on the family farm. It is also indicated that many Japanese still value what is left of their countryside and rural life. Therefore, Japanese parents, grandparents, and other relatives do not want land that had been in their family to be sold off.

Without family support and their pride in the family tradition itself, the survival of the family farm would be impossible. The elder family members such as mothers are always responsible to assist her son in managing their family farm. Additionally, her role is beyond assisting the son as she is also responsible to transfer the farming knowledge and teach her son all knowledge of farm practices. The finding of family support on a farm's survival corroborates with Tweeten et al. (1993) who argued that without generous mothers and fathers, the family farm as we have known would only last one generation. The researchers elaborated further that the Japanese continue to have generous parents who transfer their farming skills and assets to their sons and daughters, ensuring the survival of the family farms.

There was a negative perception of farming for the past half-century, a period in which the economy grew mainly on the successful manufacturing sector. People and Bailey (2005) claimed that in the 1970s, many of Japan's rural people left the family farms in search for a better life in the city because farming had often been portrayed as ailing, unprofitable and wearisome, among other things. However, there are signs of budding interest in farming, especially among young people in Japan (Obikwelu et al., 2018). This is because farming has become more common for people who used to work in different industries and later find agriculture as a career. For instance, a "U-turner", refers to someone who returns to their hometown, or an "I-turner" that refers to those who move to the country from a city. The finding of this study that reveals several participants who returned to their family farms is parallel with Obikwelu et al. (2018) who agreed that most I-turners attached great importance on revitalizing the existing economic activities, notably agriculture and forestry as they found out farming is exciting and cool as a lot of money can be made if they 
are creative enough. Apart from that, the opportunity to reconnect with nature makes them more passionate to become farmers. This is supported by Marsden (2018) who argued that farming integrates food and nature by facilitating experiences in caring for soil and plants.

Farming can be lucrative if modern technology is applied and the farm size is increased to reduce the cost while increasing profitability. The lucrative profit that farming brings may alter its negative perception of dirty, dangerous, and difficult farming work as well as the image of poverty that is often associated with rural farmers. Thus, in one way or another, a change in perception towards farming may attract investment and youths into agricultural food production. In Japan, the youngsters who have decided to become the U-turner or I-turner and then participating in agriculture proved that farming can be productive and profitable. Although this newly emerging identity of new farmers does not provide high social status in terms of economic affluence, at least it is emotionally rewarding for the holders. This is in line with Schor (2001) who stated that farmers reduce their working hours (and generally, in consequence, their income and consumption levels) in the pursuit for nonmaterial goals such as leisure time, better family relations, and reduced stress.

The setting of the working environment is subjected to one's preferences. Therefore, every individual prefers a workspace that is distinct from other counterparts. Some may prefer to work in a crowded place while others may like the quiet and peaceful working environment. Living the lifestyle in rural settings need less money and more spiritual enrichment resulting in contentment. Rural dwellers are content with their lives, consuming less and finding what they need to consume to avoid wasting available resources. In addition, since agriculture is part of their daily lives, they cannot help but shift their focus to the natural world. The finding on this aspect is consistent to what Hasegawa (2009) reported in his research that in the act of growing things, people experience and begin to harmonize with nature, connected in mind and body to the cycles of life. In the modern era, where the places of production and consumption are almost completely separated, involvement in growing things could be instrumental for many in regaining a sensitivity to and sensibility about the natural world.

\section{Conclusion}

All things considered, being in the agriculture sector today is indeed a challenging task. This is due to the lack of interest among youth towards the industry and it is not only in Japan that this situation persists but around the world. The data analysis of 7 interviews with self- employed youth farmers in Japan has allowed the researchers to unfold the real phenomenon of youth perception, experiences, their reasons of participating as well as their well-being in the agricultural industry. Along with all these factors, all participants agreed that agriculture is a viable mean in pursuing their dream to have a better and successful life. The factors such as family support, family tradition, and working environment that meets one's preferences are also significant for them to be in the industry. If the current youth farmers can prove themselves to be successful in the industry, more youths will be drawn to participate in the industry and help to sustain it. Another factor that attracts young Japanese to do farming is the naturalfriendly settings in rural areas that are serene and hasslefree from the hustle and bustle of the big city environment. Therefore, the slow pace of life in rural Japan has converted more young people into farming. This is vital to solve the problem related to the lack of participation of Japanese youth in the industry.

\section{Conflict of interest}

The authors have declared no conflict of interest.

\section{Acknowledgements}

The authors would like to acknowledge the support from Sumitomo Foundation Japan and Universiti Teknologi MARA (UiTM) Sarawak Campus.

\section{References}

Abdullah, A. \A. and Sulaiman, N.N. (2013). Factors That Influence the Interest of Youths in Agricultural Entrepreneurship. International Journal of Business and Social Science, 4(3), 288-302.

Brooks, K., Zorya, S., Gautam, A. and Goya, A. (2013). Agriculture as a Sector of Opportunity for Young People in Africa. Policy Research Working Paper 6473. World Bank Group E-Book. https:// doi.org/10.1596/1813-9450-6473

Economy-watch. (2013). Economy watch Web Page. Retrieved on July 10, 2020 from Economy watch Website: https://www.economywatch.com/ world_economy/japan/structure-of-economy.html

Feldhof, T. (2014). Japan Food Security Issues: A Geopolitical Challenge for Africa and East Asia? Journal of Global Initiatives: Policy, Pedagogy, Perspective, 9(1), 75-96.

Filmer, D. and Fox, L. (2014). Youth Employment in Sub-Saharan Africa. The World Bank Africa Development Series. Washington, DC: World Bank. https://doi.org/10.1596/978-1-4648-0107-5 
Hasegawa, H. (2009). Japanese turn to farming to find fulfilment. Ecologist the Journal for The PostIndustrial Ages. Retrieved on July 9, 2020 from The Ecologist website: https://theecologist.org/2009/ jul/23/japanese-turn-farming- find-fulfilment

Hays, J. (2009). Agriculture in Japan: Old, Part Time Farmers, Small Farms, High-Tech Methods and Imports and Exports. Retrieved on June 21, 2019 from Facts and Details website: http:// factsanddetails. comjapan/cat24/sub159/ item941.html

Hays, J. (2012). Japan. Retrieved on July 27, 2020 from Facts and Details website: http://factsanddetails.com/ japan/cat24/sub159/item940.html

Kumar, R. (2011). Research Methodology: a step by step guide for beginners. (3rd ed). Retrieved Retrieved on October 6, 2019 from Sociology website: http:// www.sociology.kpi.ua/wp- content/uploads/2014/06/ Ranjit_Kumar Research_Methodology_A_Step-byStep_G.pdf

Leavy, J. and Hossain, N. (2014). Who Wants to Farm? Youth Aspirations, Opportunities and Rising Food Prices. IDS Working Papers, 2014(439), 1-44. https://doi.org/10.1111/j.2040-0209.2014.00439.x

Mangal, H. (2009). Final Report on Best Practices for Youth in Agriculture: The Barbados, Grenada and Saint Lucia Experience. Report submitted to CARU, the Caribbean Regional Unit for Technical Assistance. Barbados: United Nations Development Programme (UNDP).

Marsden, T. (2018). The SAGE handbook of nature. Los Angeles: SAGE reference. https:// doi.org/10.4135/9781473983007

Obikwelu, F.E., Ikegami, K. and Tsuruta, T. (2018) The Roles of I-turn Migrants in Revitalizing Rural Communities: A Case Study of Some Selected Rural Areas in Kansai Region. Journal of Rural Problems, 54(3), 125-132. https://doi.org/10.7310/ arfe. 54.125

Otomo, Y. and Oedl-Wieser, T. (2009). Comparative analysis of patterns in farm succession in Austria and Japan from a gender perspective. Jahrbuch der Österreichischen Gesellschaft für Agrarökonomie, 18(2), 79-92.

Peoples, J.G. and Bailey, G.A. (2015). Humanity: An introduction to cultural anthropology. Stamford, United Kingdom: Cengage Learning.

Phyo, A. (2018). Agricultural Policy Platform. Retrieved on July 17, 2020 from Agricultural Policy Platform Web Site: http://ap.fftc.agnet.org/ap_db.php? id $=919 \&$ print $=1$

Schor, J. (2001). Voluntarily downshifting. In Standford,
J., Taylor, L. and Houston, E. (Eds). Power, employment, and accumulation: social structures in economic theory and practice. Armonk, New York, USA: M.E. Sharpe.

Silva, J.L., Mohamad, S.H.A., Uli, J. and Abu, S.B. (2010) Socio-demography factors that influence youth attitude towards contract farming. American Journal of Applied Sciences, 7(4), 603 - 608. https:// doi.org/10.3844/ajassp.2010.603.608

Smith, J.A. and Osborn, M. (2003). Interpretive phenomenological analysis. In Smith, J.A. (Ed). Qualitative psychology: A practical guide to research methods, p. 51-80. London: Sage.

Tweeten, L., Dishon, C.L., Chern, W.S., Imamura, N. and Morishima, M. (1993) Japanese And American Agriculture: Tradition and Progress in Conflict. 1st ed. United States: Westview Press

Yamashita, K. (2019). The Japan Times LTD. Retrieved on July 20, 2020 from The Japan Times LTD website: https://www.japantimes.co.jp/ opinion/2019/09/05/commentary/japan-commentary/ whats-behind-food-self-sufficiency-crisis/ \#.XnsA_4gzbIV 